\title{
ENTRE A JUSTIÇA DE TRANSIÇÃO E A TORTURA: UMA ANÁLISE DA CONTINUIDADE AUTORITÁRIA NO ATUAL ESTADO DEMOCRÁTICO DE DIREITO
}

\author{
BETWEEN TRANSITION JUSTICE AND TORTURE: AN ANALYSIS OF \\ AUTHORITARY CONTINUITY IN THE CURRENT DEMOCRATIC STATE OF
}

\section{LAW}

\author{
Cândice Lisbôa Alves ${ }^{1}$ \\ Tharuelssy Resende Henriques ${ }^{2}$
}

\section{RESUMO}

Este artigo analisa a continuidade de condutas autoritárias no atual Estado Democrático de Direito, tanto pelas instituições de segurança pública quanto pelos demais órgãos do Estado. Objetiva-se, assim, abordar a (in)efetividade da justiça de transição quanto ao pilar das reformas institucionais. Inicia-se o texto com um conceito de justiça de transição aliado aos pilares em que se desdobram, dando prioridade para análise e necessidade de reforma do pilar das reformas institucionais. Após, aborda-se a prática da tortura, sob um olhar para o passado e para o presente, de acordo com a premissa de que apenas seu reconhecimento pode impedir sua adoção no presente e repercussão no futuro. A seguir, analisa-se a possível inconstitucionalidade da lei de anistia, considerando que a aceitação de leis de autoanistia em nosso ordenamento nada mais significa do que a incompletude de uma justiça transicional. A pesquisa foi exploratória e bibliográfica e o método adotado foi o dedutivo. Por fim, reafirmando a hipótese do trabalho, concluiu-se que não aconteceu a interrupção de métodos autoritários representados pela tortura no país, não se caminhando satisfatoriamente pela via que interliga a superação do autoritarismo pela democracia prometida pelo Estado Democrático reiniciado com a Constituição de 1988.

Palavras-chave: Justiça de transição. Reformas institucionais. Tortura. Instituições de segurança pública. ADPF 153, STF.

\footnotetext{
1 Graduou-se em Direito pela Universidade Federal de Viçosa (2004). Mestre em Extensão Rural pela Universidade Federal de Viçosa (2006). Doutora em Direito Público pela Pontifícia Universidade Católica de Minas Gerais (2013). Professora Adjunta I do Curso de Direito e Mestrado em Direito da da Universidade Federal de Uberlândia (2016). Professora das cadeiras de Jurisdição Constitucional e Organização do Estado do Curso de Graduação em Direito. Pesquisadora da área de Direitos Fundamentais e vulnerabilidades sociais. Coordenadora do Projeto de Extensão "Constituição na Escola" e "Direito e Literatura" na Universidade Federal de Uberlândia. Associada da RDL (Rede Direito e Literatura) e Professora participante do Colégio de Professores da ABDConst. Afiliação: Universidade Federal de Uberlândia. Lattes: http://lattes.cnpq.br/0539033278370084. ORCID: https://orcid.org/0000-0003-0514-5025 E-mail: candicelisboa.prof@gmail.com

${ }^{2}$ Mestranda em Direito pela Universidade Federal de Uberlândia. Especialista em Direito Constitucional pela Uniderp (2014). Bacharel em Direito pela Universidade Federal de Uberlândia (2010). Professora Substituta da Faculdade de Direito da Universidade Federal de Uberlândia - UFU. Afiliação: Universidade Federal de Uberlândia. Lattes: http://lattes.cnpq.br/4027776517133344 ORCID: https://orcid.org/0000-0001-6996-712X Email: tharuelssy18@hotmail.com
} 


\begin{abstract}
This article analyzes the continuity of authoritarian conduct in the current Democratic State of Law, both by public security institutions and by other State agencies. The objective is, therefore, to address the (in) effectiveness of transitional justice regarding the pillar of institutional reforms. The text begins with a concept of transitional justice combined with the pillars on which it unfold, giving priority to analysis of and the need to reform the pillar of institutional reforms. Afterwards, the practice of torture is approached, under a look at the past and the present, according to the premise that only its recognition can prevent its adoption in the present and repercussion in the future. Next, the possible unconstitutionality of the amnesty law is analyzed, considering that the acceptance of the laws of self amnesty in our law means nothing more than the incompleteness of transactional justice. The research was exploratory and bibliographical and the method adopted was the deductive. Finally, reaffirming the hypothesis of the work, it was concluded that there was no interruption of authoritarian methods represented by torture in the country, not walking satisfactorily along the path that links the overcoming of authoritarianism by the democracy promised by the Democratic State restarted with the 1988 Constitution.
\end{abstract}

Keywords: Transitional justice. Institutional reforms. Torture. Public security institutions. ADPF 153, STF.

\title{
1 INTRODUÇÃO
}

O processo de transição de um regime ditatorial para um regime democrático não ocorre da noite para o dia. Mais do que uma mera transição política entre regimes é preciso que haja uma efetiva consolidação do que se denominou justiça de transição.

O Brasil viveu um regime de ditadura civil-militar, entre 1964 e 1985, marcado por graves violações a direitos humanos, por uma forte repressão, por práticas autoritárias e violentas, como a prática da tortura. A transição desse regime ditatorial para o atual regime democrático contou, primeiramente, com a introdução de uma Lei de Anistia, Lei 6.683, de 28 de agosto de 1979, que, bem ou mal, estabeleceu um marco jurídico para a democratização.

Com efeito, a justiça de transição, na busca por estabelecer bases para a reconstrução democrática, deve se desenvolver em torno de quatro pilares (ABRÃO \& TORELLY, 2014, p. 71): a memória e a verdade, a reparação, a reformas institucionais e a justiça. Os pilares apontados são igualmente importantes e devem ser, com a mesma ordem de importância, efetivados, para que se possa falar em uma real justiça transicional.

Partindo da premissa de que a efetivação da justiça de transição depende do cumprimento de tais medidas, busca-se responder o seguinte problema: a justiça de transição 
foi realmente efetiva - conseguindo promover uma descontinuidade de condutas tidas como autoritárias e violentas, de forma especial no que tange a prática da tortura, e especialmente em relação ao pilar das reformas institucionais - ou se verifica uma continuidade desses atos?

Observa-se que condutas autoritárias e violentas, como no caso da tortura, ainda ocorrem na atualidade e, principalmente, por parte de agentes públicos com atribuições voltadas para a área de segurança pública. Nesse sentido, "a polícia brasileira, tanto civil como militar, é proclamada pela Anistia Internacional como a mais violenta do hemisfério ocidental" (SILVA FILHO, 2012, p. 63) ${ }^{3}$. As instituições de segurança pública, que devem em tese, e por óbvio, garantir a ordem e a segurança de toda a sociedade, por vezes acabam por gerar inseguranças e demonstrações de arbitrariedades. No mesmo sentido, os demais órgãos do Estado, na medida em que não aderem à perspectiva de Justiça de transição em todos os seus pilares, fomentam a perenidade da violência. Isto pode ser observado, inclusive, tendo em vista o resultado do julgamento da ADPF (Ação de Descumprimento de Preceito Fundamental) $153^{4}$.

Assim, a hipótese apresentada é a de que a justiça de transição não foi realmente levada a efeito em todas as demandas que tem por si mesma, neste sentido não houve uma descontinuidade de condutas autoritárias e violentas, especialmente no pilar transicional das reformas institucionais. Com efeito, a efetivação desses elementos da justiça transicional dependerá das estratégias desenvolvidas para permitir a transição política e medidas públicas correlatas a tal intento.

Desta forma, o presente artigo tem como objetivo geral analisar em que medida a incompleta justiça de transição representa uma continuidade da tortura na atualidade. O elemento de análise tortura foi escolhido como instrumento apto a representar o autoritarismo estatal da ditadura em detrimento das demandas que pugnaram pela proteção aos direitos fundamentais que eclodiram junto com a Constituinte de 1988. Quanto aos objetivos específicos pretende-se apresentar e problematizar o conceito de justiça de transição e seus pilares, com relevo para as reformas institucionais; analisar a tortura, vista pelo passado, presente e lançar perspectivas para o futuro; analisar a justiça de transição por meio da teoria do reconhecimento,

\footnotetext{
${ }^{3}$ Diversos estudos corroboram esse entendimento, contudo, no decorrer do trabalho escolheu-se apresentar o relatório "Julgando a tortura: Análise da jurisprudência nos Tribunais de Justiça do Brasil - 2005 a 2010" para demonstrar alguns dados.

${ }^{4}$ A ADPF 153 foi ajuizada em 2008 pela Ordem dos Advogados do Brasil, a fim de requer uma interpretação conforme a Constituição do $\S 1 .^{\circ}$, do artigo $1 .^{\circ}$, da Lei 6.683/79 (Lei da Anistia). O objetivo da ADPF foi o de acionar o Supremo Tribunal Federal para que se posicionasse sobre os limites da lei de anistia: se a anistia concedida pela lei aos crimes políticos ou conexos se estendia (ou não) aos crimes comuns praticados pelos agentes da repressão contra opositores políticos durante o regime militar.
} 
especialmente da teoria de Axel Honneth, e entremeá-la com a atuação do Supremo Tribunal Federal como um dos agentes estatais aptos a promover uma ressignificação das possibilidades da justiça de transição no país, especialmente pela contraposição entre a ADPF 153 e a decisão da Corte Interamericana de Direitos Humanos no caso da Guerrilha do Araguaia.

A pesquisa foi exploratória e bibliográfica. $\mathrm{O}$ método adotado foi o dedutivo partindose de uma premissa maior, qual seja a incompletude da justiça de transição no país, no que tange ao pilar das reformas institucionais, e que combinada com uma premissa menor, que se refere à continuidade da tortura na atualidade, permitiu-se chegar à conclusão de que ambas estão relacionadas de forma causal. Ao final da pesquisa reafirmou-se a hipótese de trabalho, ou seja, constatou-se que não aconteceu a interrupção de métodos autoritários representados pela tortura no país, ou seja, que não se caminhou satisfatoriamente pela via que interliga a superação do autoritarismo pela democracia prometida pelo Estado Democrático reiniciado com a Constituição de 1988.

\section{A JUSTIÇA DE TRANSIÇÃO E AS REFORMAS INSTITUCIONAIS}

Para compreender o atual momento da democratização brasileira é necessário percorrer uma trajetória que tem como paradigma a Justiça de Transição. No Brasil, a discussão desse paradigma está relacionada à maneira como a lei da anistia (Lei 6.683, de 28 de agosto de 1979), aprovada ao fim da ditadura civil-militar que perdurou de 1964 a 1985, vem sendo interpretada e aplicada pelo Estado brasileiro.

A Lei da Anistia, bem ou mal, em um primeiro momento, pôde ser vista como um marco jurídico inicial para redemocratização. Em que pese este momento ser definido, em uma primeira fase da luta pela anistia (ABRÃO \& TORELLY, 2014) ${ }^{5}$ como uma ideia de impunidade e esquecimento, a sociedade viu na lei da anistia uma forma de resgatar sua liberdade política e civil, enquanto o regime militar ditatorial viu uma forma de não ser punido pelas atrocidades provocadas.

Desta forma, este foi um primeiro parâmetro. No momento político em que a lei de anistia foi criada não se vislumbrou outra forma para a redemocratização, entretanto não existia

\footnotetext{
${ }^{5}$ Entende-se de extrema importância e pertinência analisar as mutações do conceito de anistia na Justiça de Transição Brasileira, conforme proposta por Paulo Abrão e Marcelo D. Torelly (2014). Para os autores, na primeira fase da luta pela anistia tem-se a anistia enquanto impunidade e esquecimento. Na segunda fase da luta pela anistia, encontra-se a anistia enquanto memória e reparação. E, por fim, na terceira fase da luta pela anistia, tem-se a anistia enquanto verdade e justiça.
} 
uma relação de igualdade e equidade, mas sim havia "de um lado, os governantes e a força de suas armas, de outro, a sociedade civil criminalizada, presa ou pelas grades de ferro ou pelas leis ilegítimas de exceção" (ABRÃO \& TORELLY, 2014, p. 68), não podendo assim dizer que a anistia teve um caráter bilateral. Assim, em verdade, o que a lei de anistia representou foi impunidade e esquecimento.

Entretanto, posteriormente, com o advento da Constituição Cidadã de 1988, o que se tem é que a anistia passa a ser vista também como reparação ${ }^{6}$. Nesse sentido, o conceito de anistia defendido pela sociedade civil desde a década de 1970, como liberdade, foi incorporado pela $\mathrm{CR} / 88$, que não se conformou com a ideia de anistia como esquecimento e impunidade, $\mathrm{e}$ desenvolvendo o processo de redemocratização, trouxe o elemento reparatório. Temos, então, um conceito de anistia conjugado, isto é, anistia como liberdade e reparação (ABRÃO \& TORELLY, 2014).

Assim, com a segunda fase da luta pela anistia é possível falar na corrosão de um passado de negação e esquecimento, restando presente, no entanto, ainda a impunidade, vez que assegurada até os dias atuais pelos tribunais superiores, através da persistência da leitura dada a anistia de 1979 (ABRÃO \& TORELLY, 2014, p. 75).

Nesse sentido, tem-se que a Lei de Anistia abre espaços para a reflexão sobre o paradigma da Justiça de Transição, que não deve ser confundido com uma mera transição política. Trata-se, em verdade, de uma transição institucional e organizacional que busca romper com um passado ditatorial, autoritário, marcado pela repressão, violência e graves violações aos direitos humanos, e passar para um futuro que busca uma sociedade democrática, justa, igualitária, lastreada no estado democrático de direito.

De acordo com Paul van Zyl (2005, p.47), a justiça transicional pode ser definida "como o esforço para a construção da paz sustentável após um período de conflito, violência em massa ou violação sistemática dos direitos humanos”. Por sua vez, para Jon Elster (2006, p.15) "a justiça de transição é composta por juízos, expurgos e reparações que têm lugar no período de transição de um regime político para o outro".

O objetivo primordial da justiça de transição é reconhecer o significado social dos conflitos do passado, particularmente as derrotas, na tentativa de reconstruir os seus efeitos presentes e futuros. Assim, toda a questão é colocada novamente após a passagem do tempo, o

\footnotetext{
${ }^{6}$ A anistia enquanto reparação consolidou-se no art. $8^{\circ}$ do Ato das Disposições Constitucionais Transitórias (ADCT), e dirigiu-se àqueles que foram atingidos por atos de exceção. "Portanto, a anistia constitucional dirigiuse aos perseguidos políticos e não aos perseguidores, omitindo-se quanto a anistia a crimes políticos e conexos" (ABRÃO \& TORELLY, 2014, p. 71).
} 
que ressalta o desafio inicial de permanecer na história, assim como os limites para que haja transformação (TEITEL, 2003, p. 87).

A grande questão que se coloca é como o esforço para a construção da paz sustentável após um longo período de violações de direitos humanos poderá ser desenvolvido. Partindo então do pressuposto de que a justiça de transição não coaduna com o esquecimento e com a impunidade, e não se contenta com a satisfação de apenas um dos pilares, qual seja o reparatório, tem-se que, conglobando todos os conteúdos acima apresentados, do ponto de vista prático, a justiça de transição se desenvolve em torno de quatro pilares fundamentais (ABRÃO \& TORELLY, 2014, p. 71), quais sejam: direito à memória e à verdade, direito à reparação, direito às reformas institucionais e direito à justiça. Tais direitos têm por objetivo promover o reconhecimento como forma de se evitar que os mesmos erros do passado sejam novamente cometidos no futuro.

Com efeito, o pilar do direito à memória e à verdade pode ser considerado um pressuposto para que os outros pilares possam existir. É preciso primeiramente que os fatos sejam esclarecidos e reconhecidos para que se vislumbre a possibilidade de punição dos culpados, para que se reparem as vítimas e para que seja possível determinar quais instituições serão passíveis de reformas e em quais medidas estas deverão ser realizadas.

No que tange ao pilar designado de direito à memória, tem-se que esta poderá ser tanto individual como coletiva. Por individual compreende-se um complexo processo de arquivamento, tanto de informações quanto de experiências vivenciadas ou transmitidas, enquanto que por coletiva compreende-se o conjunto de experiências compartilhadas entre os integrantes da sociedade acerca dos fatos, das pessoas, dos sentimentos e sentidos (LEMOS, 2014, p. 44).

Quanto ao direito à verdade, pugna-se pela satisfação de diversas obrigações pelo Estado, que deve propiciar aos indivíduos acesso a informações sobre os fatos ocorridos por parte das vítimas, de suas famílias e toda a sociedade. Assim, estabelecer uma verdade oficial ${ }^{7}$ sobre um passado desumano pode possibilitar uma sensibilização das futuras gerações contra um revisionismo e possibilitar que os cidadãos reconheçam e resistam a um retorno de práticas abusivas (ZYL, 2005, p.51).

\footnotetext{
${ }^{7}$ Verdade oficial esta que deverá ser declarada e reconhecida pelo Estado. O direito à verdade impõe ao Estado tanto uma obrigação individual, de apresentar informações específicas sobre as diversas violações aos direitos humanos, inclusive identidade de autores, localização de restos mortais das vítimas, como também uma obrigação coletiva, de fornecer informações amplas, como razões e circunstâncias do ocorrido (BRASIL, 2014, p. 94). Em verdade, o reconhecimento pelo Estado dos erros praticados por seus agentes no passado trata-se de um primeiro passo para a efetivação da justiça de transição.
} 
Nesse aspecto importante destacar a importância da Comissão Nacional da Verdade $(\mathrm{CNV})^{8}$ tanto para a elucidação de fatos ocorridos no passado como para uma perspectiva de reconstrução e reconciliação com o futuro, de modo que práticas autoritárias e qualquer tipo de violência estatal seja abominada e valores democráticos sejam fortalecidos. A CNV no Brasil, que teve seu surgimento em 2011, em virtude da Lei 12.528/11, foi acompanhada pela constituição de comissões da verdade em todo o país, e que tiveram por finalidade examinar e esclarecer as graves violações de direitos humanos praticadas no período de 1946 a $1988^{9}$. No entanto, destaca-se que no Brasil a CNV não possui poderes judiciais, nada impedindo, contudo, que as informações coletadas nas comissões sejam posteriormente apresentadas ao Judiciário.

Por sua vez, no que tange ao pilar da reparação tem-se que as vítimas das mais diversas violações de direitos humanos deverão ser ressarcidas. Em um primeiro momento poder-se-ia imaginar a reparação apenas no plano material, a título de indenização em dinheiro, mas a reparação deverá ir além, para um plano psicológico e simbólico. A reparação simbólica constitui medida para o restabelecimento da dignidade das vítimas, uma vez que pugna pela reconstrução histórica, através da construção de memoriais e monumentos, alteração de nome de ruas, viadutos, escolas, dentre outras medidas. A reparação psicológica, por sua vez, busca promover assistência psicológica às vítimas, restabelecendo suas concepções de mundo, devolvendo-lhes a ideia de pertencimento.

Com efeito, no que tange ao pilar da justiça tem-se a noção de punibilidade dos perpetradores das mais diversas violações aos direitos humanos. Sendo assim, a punição dos agentes criminosos é medida que se impõe tanto para que haja uma resposta direta aos indivíduos e familiares que sofreram as violações, como também uma resposta a toda sociedade, que precisa sentir confiança e segurança de que aqueles que praticam delitos serão punidos. Assim, "os julgamentos podem servir para evitar futuros crimes, dar consolo às vítimas, pensar um novo grupo de normas e dar impulso ao processo de reformar as instituições governamentais, agregando-lhes confiança" (ZYL, 2005, p. 49).

\footnotetext{
${ }^{8}$ Dispõe Torelly (2014, p. 219) que “uma comissão da verdade é, portanto, um mecanismo do Estado com poderes e prerrogativas especiais para a busca da verdade, que não será, ao final, uma verdade judicial (sem com isso deixar de ser uma verdade "ajuizável"), e que foca-se muito mais nas vítimas do que nos perpetradores".

${ }^{9}$ De acordo com Torelly (2014), a CNV no Brasil foi criada com alguns objetivos, sendo os principais: a) Esclarecer fatos e circunstâncias de graves violações de direitos humanos; b) Promover esclarecimento circunstanciado de torturas, mortes e desaparecimentos, identificando autorias; c) Identificação das estruturas e locais das violações aos direitos humanos; d) Encaminhamento das informações obtidas aos órgãos responsáveis pela localização dos restos mortais dos mortos e desaparecidos e colaboração com o Poder Público para o esclarecimento de todas as violações aos direitos humanos; e) Recomendação de medidas e políticas públicas de não-repetição; f) Promoção da reconstrução histórica sobre as graves violações contra os direitos humanos.
} 
Entretanto, no que tange a este pilar da justiça, no Brasil não houve até os dias atuais uma condenação penal, em âmbito interno, nem ao menos uma investigação criminal que tenha por objetivo descobrir a materialidade e autoria dos fatos praticados durante a ditadura militar ${ }^{10}$.

Mais ainda, para que os crimes cometidos no passado não se repitam novamente é preciso mais do que conceder direitos à verdade e à memória - com o esclarecimento dos fatos -, direito à reparação - como forma de reparar todos os danos materiais e morais sofridos -, e direito à justiça - como forma de punição aos violadores de direitos humanos. É preciso que haja a dissolução ou mudança radical de certas instituições que foram responsáveis pelas atrocidades. Trata-se, assim, de outro pilar importante da justiça de transição, o das reformas institucionais.

Durante o regime militar presenciou-se um forte autoritarismo, prevalecendo a vontade dos militares que estavam no poder. Nesse período, vários direitos e garantias individuais foram suspensos, partidos políticos foram extintos, eleições presidenciais foram suprimidas, governadores foram depostos, funcionários públicos foram demitidos ou compulsoriamente aposentados, mandados políticos foram suspensos e direitos políticos foram cassados.

As torturas eram práticas recorrentes e nos anos de chumbo, após 1968, foram intensificadas. Conforme descreve Heládio José de Campos Leme (2009, p. 288):

[...] batidas policiais passaram a ser frequentes, pessoas sequestradas e presas a esmo sem qualquer mandado judicial, a repressão atingia a todos que tivessem a mais remota ligação com a oposição (...) A generalização do arbítrio e o poder sem limites conferidos pelo AI-5 deram aos policiais "carta-branca" para o uso indiscriminado da força, que ultrapassou o próprio objetivo político atingindo também os costumes: cabelos compridos e barba faziam do sujeito um suspeito em potencial.

Nessa época organismos militares foram criados com o objetivo de centralizar todas as operações de informação, inteligência e segurança, como o DOI-CODI (destacamento de operações de Informações - centro de operações de defesa interna), órgão subordinado ao exército responsável pela repressão do governo.

As instituições de segurança pública nesse momento histórico eram responsáveis pelas mais diversas violações de direitos humanos, como a tortura. Nesse contexto, a justiça de transição tem como um dos objetivos reformar as instituições, sendo que tal reforma deverá em

\footnotetext{
${ }^{10}$ Importante frisar que as investigações que ocorreram até então no país, como as realizadas pela CNV, estiveram relacionadas com a efetivação de outros pilares da Justiça de Transição, como resgate a memória e a verdade sobre as graves violações aos direitos humanos ocorridas entre 1946 a 1988, não tendo implicações no pilar da Justiça, que objetiva a responsabilização criminal dos agentes perpetradores de violência no período ditatorial.
} 
alguns casos promover até mesmo a dissolução de mecanismos de repressão, como organismos militares tal como o DOI-CODI.

Conforme Zyl (2005, p. 54), “a remoção das pessoas que violaram direitos humanos de cargos que implicam confiança e responsabilidade constitui uma parte importante do processo para estabelecer ou restaurar a integridade das instituições estatais". Trata-se de um processo conhecido como depuração administrativa, que deve ser visto "não somente como medida de sanção pelas condutas ilícitas, mas também para permitir que os resquícios autoritários e antidemocráticos sejam expurgados das instituições" (LUNARDI, 2012).

Com efeito, em outros casos, quando não se mostrar possível a dissolução de órgãos de segurança pública indispensáveis para a vida em sociedade, como, por exemplo, no caso das polícias, uma reforma radical deverá ser promovida. Para tanto, com a finalidade de desenvolver perspectivas democráticas e de direitos humanos norteadores das condutas dos servidores públicos dessas instituições, medidas de capacitação e reeducação filosófica, ética e humanística deverão ser criadas (LUNARDI, 2012).

Como demonstrado acima, o cerne das reformas institucionais necessárias diz respeito ao combate aos resquícios autoritários e antidemocráticos que permearam por muitos anos - e ainda permeiam, em alguns locais - o modus operandi de diversas atividades estatais. O combate necessário requer previsão normativa e também atuação social em um entrelaçamento perfeito e integrado que alie, como instrumento da democracia, "o sistema de normas, valores, crenças e tradições culturais que predomina no interior desse mesmo sistema político" (AVRITZER, 1995). Entretanto, não se pode ter a ilusão de que este entrelaçamento se dê em um único instante, e sim que seja uma nova postura em continuidade posto que "atores autoritários não abandonam rapidamente suas restrições ao livre funcionamento das instituições políticas. (...) a democracia é em geral alcançada através de um processo longo de negociação, no qual são criadas garantias recíprocas entre governo e oposição" (AVRITZER, 1995).

O fenômeno da redemocratização, que tem como marco a já mencionada Lei de Anistia, pode ser considerado, na linha de Avritzer (1995), uma negociação (ZAVERUCHA, 2010), todavia há muitas críticas sobre a forma como ela ocorreu, especialmente sobre ela ter correspondido ou não aos anseios sociais $^{11}$ (ZAVERUCHA, 2010). Em continuidade,

\footnotetext{
${ }^{11}$ Na decisão da ADPF 153 o relator deixa claro que esta discussão não deveria acontecer, ou seja, que o conteúdo da lei de anistia ao tempo em que foi elaborado correspondeu aos anseios sociais atintes ao processo de redemocratização, tanto é assim que na decisão não se anuiu com o argumento de invalidação do conteúdo da lei. Embora esteja assim decidido não se partilha o entendimento, sob pena de engessamento de um escavamento no conteúdo de proteção necessário aos direitos humanos, especialmente o direito à memória e a verdade,
} 
analisando-se as disposições constitucionais de 1988, nota-se que, em que pese o texto constitucional ter avançado em inúmeros sentidos, trazendo, por exemplo, benefícios sociais equivalentes aos das democracias mais avançadas, manteve partes idênticas à Constituição autoritária de 1967, e de sua emenda de 1969, especialmente no que se refere ao título V, "Da defesa do estado e das instituições democráticas", precisamente no que tange às forças armadas, polícias militares estaduais, sistema judiciário militar e de segurança pública em geral (ZAVERUCHA, 2010, p. 45).

Nesse sentido, Avritzer (1995) dispõe que:

[...] Eleições livres e garantia de direitos civis pela Constituição aparecem como variáveis a medir. $\mathrm{O}$ problema envolvido em tal concepção é um problema metodológico, na medida em que as teorias da transição deixam de problematizar a forma como os diferentes atores políticos incorporam a institucionalidade vigente. Nesse sentido, tão importante quanto a realização de eleições ou a existência de uma boa declaração de direitos na Constituição é analisar a atitude dos sujeitos sociais em relação a esses atributos. (...) No caso de um país como o Brasil, seria pelo menos tão importante quanto a análise sobre a vigência de direitos, entender porque a ação cotidiana de atores políticos relevantes tais como governantes, membros do sistema judiciário e da própria polícia não se orientam pela normatividade existente. Trata-se de compreender que existe uma cultura política não-democrática que se entrelaça com a institucionalização democrática. As práticas dominantes, nesse caso, não são puramente democráticas nem puramente autoritárias [...].

Portanto, a análise da democracia deverá levar em conta a cultura política estabelecida no regime autoritário, assim como os locais do aparelhamento estatal e do sistema político que favorecem a continuidade de práticas autoritárias (AVRITZER, 1995). Para além disso, a democratização deve ser pensada como um longo processo de interiorização de princípios democráticos pela própria sociedade, o que não ocorreu de forma plena, vez que diversos órgãos estatais ainda não incorporaram em sua estrutura e funcionamento os princípios da ordem democrática. "A adoção de uma tal perspectiva tem a vantagem de estabelecer uma continuidade entre o processo de negociação para a retirada de atores autoritários do sistema político e o processo de democratização das relações Estado-sociedade" (AVRITZER, 1995).

Assim sendo, não se pode considerar que um regime simplesmente findou-se por que do dia para a noite nasceu uma Constituição Democrática e instaurou-se uma democracia. Não se faz uma ditadura ou uma democracia simplesmente no papel, mas sim, e principalmente, através dos atos praticados pelos agentes estatais.

conjuntamente com a noção de dignidade humana, todos preceitos fundamentais robustamente defendidos na inicial da ADPF 153. Vale a pena, entretanto, apontar a posição do STF a respeito. 
Nas palavras de Ricardo C. Carvalho Rodrigues (2017):

Se em 1973 o Brasil tinha uma ditadura militar repressora, em 1989 tinha uma "democracia completa". Dessa constatação Hundington extrai uma conclusão aterradora: a de que "não houve, de fato, nenhum corte claro; a característica da transformação brasileira é ser virtualmente impossível dizer-se em que ponto o Brasil deixou de ser uma ditadura e tornou-se uma democracia". Enfim, não reconhecemos as diferenças entre um regime autoritário e um democrático. Se não sabemos se somos democráticos, então podemos conviver facilmente com qualquer instrumento autoritário e os novos dirigentes políticos andam à cavaleiro nestes instrumentos.

Desta forma, precisa-se analisar até que ponto é possível falar em continuidade e até que ponto se fala em descontinuidade. Muito interessante o questionamento e as conclusões de Ricardo C. Carvalho Rodrigues (2017):

Tivemos uma transição ou uma extraordinária e obscura continuidade? A resposta dependerá de onde parte a análise. Uma análise política, como fizeram os primeiros transitólogos, afirmará a transição. Uma análise qualitativa da democracia que percebemos hoje dirá que continuamos autoritários, escondidos por detrás de um verniz democrático. Somos maciçamente autoritários. Pôr em marcha um projeto democrático no Brasil significa mudar a cultura, e como nos advertiu certa vez Engels, mudar uma cultura é a mudança mais difícil e, completo, a mais lenta e a mais perigosa das mudanças das mentalidades, pois não se sabe no quê nos transformaremos. Talvez democráticos, mas conforme nossa história, não oscilamos entre democracia e autoritarismo, mas entre um autoritarismo puro e um autoritarismo disfarçado de democracia.

Importante ressalvar que embora não exista uma fronteira certa entre períodos ordinários e períodos de transição, a busca da justiça nos períodos de transição é diferenciada em razão das condições políticas estabelecidas pelo Estado de Direito. Quando o regime sucessor ainda tem a presença de condições políticas que eram presentes no regime autoritário, as circunstâncias apresentarão desafios de Estado de Direito que são peculiares ao contexto de transição. Portanto, é preciso ter em mente que enquanto desejável insistir que os projetos de justiça nos tempos de transição imitem os das democracias liberais estabelecidas, pela exortação em sua normativa interna de ideais democráticos, será em última análise uma orientação normativa limitada, vez que não se pode esperar que a capacidade do Estado de Direito das sociedades que vivem a transição funcione no mesmo nível que os estados que possuem um aparato jurídico liberal consolidado (TEITEL, 2003, p. 93).

Pelo exposto, a justiça de transição, principalmente no que tange ao pilar das reformas institucionais, deve se preocupar em promover mudanças significativas, de modo que não haja apenas uma fictícia ruptura de um regime para o outro, mas sim uma efetiva concretização dos 
propósitos democráticos defendido, contando com uma verdadeira mudança das condições políticas, em busca de uma democracia liberal estabelecida.

\section{TORTURA: UM OLHAR PARA O PASSADO, PARA O PRESENTE E PARA O FUTURO}

A prática da tortura não é atual, mas sim remonta à Antiguidade. Ao longo de toda a história a tortura foi praticada por diversas razões, como por motivações políticas, religiosas, sociais, econômicas, entre outras. Zulmar Fachin (2007, p. 442), a esse respeito, dispõe que “(...) parece não ser possível identificar o momento exato em que foi utilizada pela primeira vez, mas é provável que a tortura seja tão antiga quão antigo é o sentimento do homem de dominar despoticamente outro homem".

Ao longo do século XX, século este marcado pelas mais diversas violações aos direitos humanos, por extermínios, genocídios, guerras mundiais, atos terroristas, desaparecimentos forçados, destruições em massa, a tortura continuou a ser veementemente utilizada. Passou a ser praticada em todas as partes do mundo, com a finalidade de garantir regimes políticos autoritários, como o nazismo, o fascismo, o comunismo, e, nos países da América Latina, o poder dos regimes militares. Nesse sentido, verifica-se que a tortura ao longo de toda história foi utilizada como instrumento de poder.

No Brasil, tivemos um período de ditadura militar caracterizado pela intensa prática de tortura. No momento histórico também conhecido como "Estado Novo" (1937-1945), da Era Vargas, caracterizado pela supressão de garantias individuais, liberdades civis e políticas, a tortura foi institucionalizada. Nesse período as torturas eram praticadas contra os presos políticos, tidos por opositores ao regime militar, tanto como um meio de obtenção de provas, através da confissão, como um meio de punição aos rebeldes.

As torturas consistiam tanto em maus tratos físicos quanto em maus tratos psicológicos, ferindo não apenas o corpo, ao deixar marcas e cicatrizes, mas também ferindo a alma, a dignidade, ao causar dores, angústias, medos e diversos distúrbios.

As torturas, durante a ditadura civil-militar pós-1964, eram realizadas pelos militares que importaram determinadas técnicas da Escola das Américas. As vítimas eram levadas a centros de torturas e lá eram submetidas ao mais alto grau de humilhação, ofensa e rebaixamento pessoal. As vítimas eram obrigadas a retirar suas vestes e nuas eram submetidas aos mais variados métodos de tortura: pau-de-arara, choque elétrico, afogamento, cadeira do 
dragão, geladeira, palmatória, produtos químicos, agressões físicas, torturas psicológicas, entre outras.

Em 1979, foi introduzida em nosso ordenamento jurídico uma lei de anistia, que, como já visto anteriormente, teve por escopo promover o perdão judicial a todos que cometeram crimes políticos e conexos. Desta forma, os mais bárbaros crimes cometidos sob a égide da ditadura, como os crimes de tortura, não foram elucidados e punidos.

Em 1988, com o nascimento da Constituição da República, o Brasil presencia um processo de redemocratização, ao trazer um piso normativo afeto aos direitos fundamentais. Portanto, a CR/88 institui o estado democrático de direito que abraça, e traz como um dos seus principais fundamentos, a dignidade da pessoa humana.

No Brasil, neste cenário de redemocratização e de acolhimento de uma concepção contemporânea dos direitos humanos, sob a égide da Constituição Federal de 1988, importantes tratados de direitos humanos foram incorporados, como: a) da Convenção Interamericana para Prevenir e Punir a Tortura, em 20 de julho de $1989^{12-13}$; b) da Convenção contra a Tortura e outros Tratamentos Cruéis, Desumanos ou Degradantes, em 28 de setembro de $1989^{14}$; c) do Pacto Internacional dos Direitos Civis e Políticos, em 24 de janeiro de $1992^{15}$; e) da Convenção Americana de Direitos Humanos (Pacto de São José da Costa Rica), em 25 de setembro de $1992^{16}$, dentre outros.

\footnotetext{
12 Adotada pela OEA em 9 de dezembro de 1985, ratificada pelo Brasil em 20 julho de 1989, entrou em vigor em 20 de agosto de 1989. Pretendeu tornar efetiva as normas contidas nos instrumentos universais e regionais já dispostos na Declaração Americana dos Direitos e Deveres do Homem e na Declaração Universal dos Direitos do Homem, reiterando o propósito de consolidar as condições que permitam o reconhecimento e o respeito da dignidade inerente à pessoa humana e assegurem o exercício pleno das liberdades e direitos fundamentais. Dentre as inúmeras contribuições, estabelece a definição do conceito de tortura, especifica os sujeitos que poderão ser responsáveis por este ato, traz a obrigação aos Estados-partes de incriminar os atos de tortura em seus ordenamentos internos, cominando penas severas e a obrigatoriedade de se proceder imediatamente a investigações imparciais.

${ }^{13}$ Conforme a Convenção Interamericana para Prevenir e Punir a Tortura (1985), entende-se por tortura: [...] todo ato pelo qual são infligidos intencionalmente a uma pessoa penas ou sofrimentos físicos ou mentais, com fins de investigação criminal, como meio de intimidação, como castigo pessoal, como medida preventiva, como pena ou com qualquer outro fim.

${ }^{14}$ Adotada em 1984 pela Assembleia Geral das Nações Unidas, ratificada pelo Brasil em 28 de setembro de 1989, entrou em vigor 28 de outubro de 1989, buscou promover o respeito universal e a observância dos direitos humanos e liberdades fundamentais. Dentre suas contribuições, observa-se a conceituação de tortura, a definição de agentes, proclamação de princípios como o da inderrogabilidade da proibição de torturar, previsão como crime internacional, criação de comitês, dentre outras.

${ }^{15}$ Adotado pela Assembleia Geral das Nações Unidas em 1966, depositada em 24 de janeiro de 1992, entrou em vigor no Brasil em 24 de abril de 1992. Reconhece o gozo das liberdades civis e políticas, trazendo como uma das principais contribuições a consagração de diversos direitos fundamentais da pessoa humana, dentre os quais o direito à vida e o direito de não ser submetido à tortura ou penas ou tratamentos cruéis, desumanos ou degradantes. ${ }^{16}$ Adotada pela OEA em 22 de novembro de 1969, ratificada pelo Brasil em 25 de setembro de 1992, entrando em vigor nesta mesma data, é um dos poucos tratados incorporados ao Direito Brasileiro com status de norma constitucional. Estabelece diversos direitos fundamentais da pessoa humana, dentro os quais o direito à vida, à
} 
No Brasil, em 1997, a lei de tortura (Lei 9.455/97) foi elaborada com a finalidade de assegurar o princípio constitucional da dignidade da pessoa humana e sua tipificação se mostra como uma evolução no ordenamento penal brasileiro. Sua elaboração teve ainda por objetivo reafirmar os compromissos internacionais assumidos pelo Brasil e demonstrar a consciência de que os atos desta natureza são dotados de relevância e merecem repúdio.

Ademais, a Constituição Federal em seu art. $5^{\circ}$, XLIII, dispõe que a prática de tortura é crime inafiançável e insuscetível de graça ou anistia, constituindo um verdadeiro mandado de criminalização expresso, não tendo o legislador ordinário faculdade de legislar, mas sim uma obrigatoriedade.

Este é o atual cenário brasileiro, existe o amparo de diversos tratados de direitos internacionais e há também uma legislação constitucional e infraconstitucional que proíbe veementemente a prática da tortura. Temos normas válidas e eficazes que proíbem tal conduta. O que resta saber é se tais normas estão sendo efetivadas, posto que o grande problema na atualidade não é nem a falta de positivação das normas, mas a falta de sua efetivação (BARROSO, 1993).

Entretanto, em que pese a proibição da tortura estar positivamente criminalizada, não se pode deduzir que não mais acontece. A tortura é prática atual e recorrente e pode ser considerada uma herança do período ditatorial.

De acordo com o relatório "Julgando a tortura: Análise de jurisprudência nos Tribunais de Justiça do Brasil 2005-2010”, foram selecionados e analisados 455 casos, contando com aproximadamente 800 vítimas, e constatou-se que, levando em consideração o perfil das vítimas, $42 \%$ eram homens, sendo que destes $21 \%$ eram considerados suspeitos da prática de algum tipo de crime, " $20 \%$ crianças, $13 \%$ adolescentes, $9 \%$ homens presos, $8 \%$ mulheres, $1 \%$ mulheres presas, $3 \%$ caracterizavam outros perfis e em $4 \%$ não foi possível identificar o perfil da vítima" (JESUS; CALDERONI, 2015, p. 27).

Já em relação ao perfil dos acusados, em um universo de 752 pessoas, o relatório apontou que $61 \%$ representam agentes públicos e 37\% representam agentes privados. Em 2\% dos casos não foi possível identificar o perfil do acusado (JESUS; CALDERONI, 2015, p. 31).

Quanto ao local da ocorrência, tendo como base os 455 acórdãos analisados, aparecem com maior frequência as residências, com $33 \%$ dos casos, e as casas de contenção, com $31 \%$. As torturas praticadas em vias públicas representam $16 \%$ dos casos. Ao fazer um cruzamento

liberdade, à integridade pessoal, não devendo ninguém ser submetido a tortura, nem a penas ou tratos cruéis, desumanos e degradantes. 
de dados entre o local da ocorrência e o perfil do agressor, constatou-se que os crimes ocorridos em via pública e em casas de contenção, em sua maioria, foram praticados por agentes públicos, ao passo que os crimes ocorridos nas residências, em sua maioria, foram praticados por agentes privados (JESUS; CALDERONI, 2015, p. 35/36).

Por sua vez, quanto ao propósito da tortura, tem-se que sua utilização se dá para promoção de castigo (com propósito de repreender ou punir alguém), obtenção de confissão ou informação (acerca de um crime ou de um erro), como intimidação (amedrontar ou constranger alguém) ou com outros propósitos (outras hipóteses como discriminar, humilhar, obter outros favores ou mesmo pela ausência de qualquer causa motivo aparente). Constatou-se, através da pesquisa, ao analisar os acórdãos, que quando a tortura é utilizada como meio de obter confissão ou informação aparecem como autores, na maioria dos casos, agentes públicos $(65,6 \%)$, ao passo que quando a tortura é utilizada como castigo aparecem agentes privados (61\%). (JESUS; CALDERONI, 2015, p. 37/38)

Pode-se falar ainda que a tortura que durante a ditadura era utilizada pelos militares como forma de oprimir os rebeldes do regime, tais como lideranças sindicais e operários, de classe baixa; população indígena; camponeses; negros; pobres; população LGBT; além de muitos rebeldes de classe média - o que lhes davam certo poder de voz -; hoje é utilizada pelas instituições de segurança pública praticamente contra negros, pobres e/ou outros vulneráveis, como moradores de favelas e periferias, que vivem em situação de invisibilidade a ponto de não terem poder de voz e nem mesmo condições de exporem sua situação (FELTRAN, 2015).

Assim, os torturados não se veem protegidos pelo Estado. Não recorrem ao Estado para que este lhe possa oferecer proteção, uma vez que se veem reféns, se veem vítimas das mais diversas formas de violações. O Estado que deveria proporcionar condições melhores de vida, não lhes proporciona segurança, não lhes proporciona igualdade.

Nesse contexto institucional, o que se vê na atualidade é a tortura praticada pelas instituições de segurança pública, nas mais diversas ocasiões, seja em ações de rotina nas comunidades, seja para fazer com que determinadas pessoas confessem crimes, seja até mesmo a tortura dentro de delegacias de polícia e penitenciárias.

De acordo com Giovani Saavedra, (2008, p. 98):

[...] A relação com a polícia também é marcada pela extrema violência e corrupção. Como demonstram estudos desenvolvidos nos últimos anos no Brasil, as prisões arbitrárias sem fundamento legal, as execuções sumárias e as práticas de tortura não são externalidades do trabalho policial ou práticas isoladas de policiais violentos. São ações sistemáticas, expressões de procedimentos de 
combate à criminalidade, avaliadas como legítimos por agentes das corporações policiais.

Um caso emblemático, a respeito da violência policial a grupo vulneráveis, foi o conhecido caso da Chacina da Candelária. As investigações concluíram que policiais, por motivações até hoje desconhecidas, atiraram contra dezenas de pessoas, pessoas em situação de rua, a maioria crianças e adolescentes, causando oito mortes e ferindo tantas outras pessoas (Anistia Internacional, 2013).

Outra chacina que ocorreu contando com envolvimento de agentes de segurança pública foi a chacina de Osasco e Barueri, na qual três policiais militares e um guarda civil foram acusados e condenados por executarem pelo menos 19 pessoas e ferirem outras sete em um intervalo de duas horas (Anistia Internacional, 2015).

Outras inúmeras notícias veiculam a tortura praticada por agentes de segurança pública também em presídios, como o caso da Chacina do Carandiru. Em 1992, a Penitenciária do Carandiru, em São Paulo, foi cenário da maior tragédia ocorrida dentro de penitenciárias brasileiras. A origem do massacre foi uma rebelião de presos, que, posteriormente, foi seguida por uma intervenção policial que deixou 111 mortos. Até os dias de hoje, 25 anos após o massacre, ninguém foi responsabilizado (Anistia Internacional, 2016).

Nesse sentido, diversos são os casos que demonstram a violência policial institucionalizada, além da falta de punição dos agentes perpetradores das mais diversas atrocidades, situação que chama a atenção tanto do cenário interno quanto do cenário internacional e das Organizações de Direitos Humanos.

Nos termos do art. 144 da CF/88, as instituições de segurança pública são destinadas a preservar a ordem, a segurança pública e a incolumidade das pessoas. O agente público, incumbido de respeitar e garantir tais preceitos, como no caso dos policiais, ao descumprir tais obrigações e praticar atos de tortura atinge não somente a pessoa, mas também a toda a coletividade e a instituição a que pertence de forma imediata. Assim, o que se percebe é que o uso desmensurado da violência pelos órgãos de segurança pública, em vez de reduzi-la, promove o seu fomento e compromete a credibilidade das instituições.

Nesse sentido, verifica-se que tivemos uma justiça de transição, mas que não se mostrou plenamente efetiva. A transição política não foi capaz de modificar a continuidade da gestão do aparelho estatal, que ainda se encontra atrelada a condutas e políticas autoritárias.

Em verdade, a não ruptura com as práticas produzidas no passado, o não reconhecimento, o acobertamento de diversas práticas autoritárias, mostra uma evidente 
justaposição entre práticas arbitrárias em um atual regime que se diz democrático. Nesse sentido, a ausência de memória e a falta de reformas institucionais são os principais obstáculos à consolidação democrática, pois permitem a persistência da violência ilegal e da impunidade. Sem que tais questões sejam sanadas a tortura do passado e do presente será novamente reproduzida no futuro.

Nesses termos, Roberta Camineiro Baggio e Lara Caroline Miranda (2015, p. 166), que adotam a perspectiva de que o próprio Poder Judiciário é um dos focos de (re)produção da cultura autoritária, concluem que "a ausência de uma profunda reforma das instituições pós regime de exceção coloca-se atualmente como um dos principais empecilhos para se buscar a superação de formas autoritárias enraizadas na cultura institucional em nosso país".

Nesse sentido é extremamente essencial a análise da justiça de transição como reconhecimento, sob o viés da tortura.

\section{RECONHECIMENTO, REFORMAS INSTITUCIONAIS E O SUPREMO: UM OLHAR POR MEIO DA ADPF 153}

Como já foi visto ao longo deste artigo, uma das violências mais graves praticadas contra as vítimas do regime ditatorial e que prevalece, ainda que de forma diversa, até os dias atuais é a tortura. No momento em que as vítimas são torturadas são submetidas ao mais alto grau de humilhação, ofensa e rebaixamento pessoal. Para Axel Honneth ${ }^{17}$ (2003, p. 215),

Toda tentativa de se apoderar do corpo de uma pessoa, empreendida contra a sua vontade e com qualquer intenção que seja, provoca um grau de humilhação que interfere destrutivamente na autorrelação prática de um ser humano, com mais profundidade do que outras formas de desrespeito.

Para Honneth (2003) a identidade do indivíduo é constituída por um reconhecimento intersubjetivo, que se dá em três esferas distintas: na esfera do amor, na esfera jurídico-moral e na esfera da estima social. Em contraponto, há para Honneth três formas de não

\footnotetext{
${ }^{17}$ Dois autores da contemporaneidade, no contexto da teoria crítica, trabalham com a ideia de reconhecimento: Axel Honneth e Nancy Fraser. (BAGGIO, 2014, p. 5). Entretanto, buscando um recorte metodológico, assim como desenvolvido por Baggio (2014, p. 11) “a opção será a de analisar as ofensas morais aos perseguidos políticos pela versão de reconhecimento desenvolvida por Axel Honneth, tendo em vista seu enfoque na psicologia social, e, sob o ponto de vista institucional do Estado, pelo modelo de status de Fraser, que tem como ponto de partida a investigação das condições de paridade participativa fornecidas pela estrutura institucional de produção de padrões culturais".
} 
reconhecimento, ou de reconhecimento recusado, que se dá pela violação, privação de direitos e degradação.

Tendo em vista que o processo de formação da identidade de um indivíduo leva em conta a sua relação recíproca com os demais sujeitos, a obtenção do reconhecimento intersubjetivo, proporcionada pela observância destas três esferas de reconhecimento, por produzir no indivíduo uma noção positiva de si mesmo, proporciona uma ideia de pertencimento ao Estado de Direito. Assim sendo, a concepção de reconhecimento é essencial para que os indivíduos se sintam verdadeiramente integrados ao Estado em que vivem.

Por sua vez, os indivíduos que passam por formas de reconhecimento recusado perdem esta noção de respeito por si mesmos o que, consequentemente, acaba por refletir negativamente no seu comportamento social. Com efeito, uma das formas de reconhecimento recusado mais evidentes e característicos de uma época ditatorial é a tortura.

Em verdade, inúmeras vítimas da ditadura passaram por alguma das formas de recusa de reconhecimento, o que acabou por representar algum tipo de desrespeito pessoal abalando, por consequência, a confiança que possuíam em si mesmas, no outro e no Estado. Nesse contexto, as vítimas passaram por um processo de isolamento e de exclusão social. De acordo com Baggio (2014, p. 8),

[...] a não obtenção de reconhecimento abala o processo de integração, gerando formas não democráticas de relacionamentos em sociedade ou, nas palavras de Honneth, estabelecendo formas de desrespeito ou patologias sociais que geram abalos morais nas relações. Constituem-se, portanto, experiências negativas na formação das identidades dos sujeitos, já que deixam de ter uma compreensão positiva de si mesmos, seja porque não confiam em seus pares de interação social, ou porque deixam de se sentir como iguais aos outros seres humanos ou, ainda, porque seu modo de vida é depreciado ao invés de valorizado.

Deste modo, o que se pode concluir, inicialmente, é que as vítimas de torturas passaram por todas as formas de recusa de reconhecimento, capazes de romper com uma concepção de Estado de Direito e de Estado Democrático. Como é possível falar em um Estado Democrático se garantias individuais e fundamentais são ignoradas ou mesmo violadas pelos próprios agentes estatais? Como cobrar que os cidadãos se adéquem às regras sociais, se o próprio Estado não lhes oferece poder de voz, e não lhes proporciona um pertencimento social?

Nesse contexto, aventar a ideia de justiça de transição requer ir além do pilar mais conveniente, qual seja, o reparatório. Exige a reconciliação das pessoas que tiveram seu reconhecimento recusado pelo Estado com o próprio Estado, ou seja, uma mudança de postura 
dele em relação a elas, função que apenas pode ser pensada atualmente pela revisão da ideia de anistia trazida pela Lei já mencionada.

Somente após o reconhecimento realizado pelo Estado de que agentes seus agiram de maneira equivocada durante o regime militar, ou seja, de que de dentro da força estatal foram cometidos equívocos no passado, eivados de violações aos direitos humanos, é que será possível falar em um passo efetivo para a transição que se almeja fazer rumo à pacificação entre passado, presente e futuro e resgate da história e memória das pessoas violentadas. Esta mudança de postura geraria efeitos tanto individuais - pois as pessoas que foram lesadas de forma direta e seus familiares começam a resgatar suas noções de inclusão e pertencimento social, possibilitando acreditar novamente no Estado, em si mesmos e nos outros - quanto também benefício coletivo - já que o reconhecimento dos erros praticados pelo Estado possibilita um direito à memória e, estabelecer uma verdade oficial sobre um passado eivado de arbitrariedades e violências pode possibilitar que as gerações futuras não aceitem e, inclusive, resistam ao retorno de quaisquer práticas abusivas.

O reconhecimento, a responsabilização e a punição dos perpetradores das mais diversas formas de tortura e violência, nesta senda, é tida como combate à impunidade incorporando um pensamento crítico nos agentes estatais fazendo-os refletir antes de cometerem crimes, incutindo em sua decisão a previsão de que haverá punição diante de ilegalidades praticadas. Tal postura reflete, mais uma vez, em reformas institucionais. Tudo isso é possível por meio da análise jurídica da ditadura ou dos atos praticados durante o interregno de tempo de sua existência, o que implica, por consequência, em uma reflexão acerca da Lei de Anistia, Lei 6.683, de 28 de agosto de 1979, especialmente quanto ao seu art. $1^{\text {o18 }}$. Nesse sentido, imprescindível examinar a ADPF 153 e conjecturar alternativas para revisão do conteúdo da decisão que acatou a manutenção do conceito de crimes conexos junto à anistia aos crimes políticos blindados pela legislação. Essa ressignificação do alcance da anistia não se mostra como preciosismo ou mero debate acadêmico, mas instrumento apto a conciliar verdadeiramente as premissas de uma justiça de transição ao lado, ainda, do posicionamento da Corte Interamericana de Direitos Humanos, o que se verá neste tópico ainda.

\footnotetext{
${ }^{18}$ Art. $1^{\circ}$ É concedida anistia a todos quantos, no período compreendido entre 02 de setembro de 1961 e 15 de agosto de 1979, cometeram crimes políticos ou conexo com estes, crimes eleitorais, aos que tiveram seus direitos políticos suspensos e aos servidores da Administração Direta e Indireta, de fundações vinculadas ao poder público, aos Servidores dos Poderes Legislativo e Judiciário, aos Militares e aos dirigentes e representantes sindicais, punidos com fundamento em Atos Institucionais e Complementares.
} 
A ADPF 153 foi proposta no Supremo Tribunal Federal (STF) pela Ordem dos Advogados do Brasil, para que fosse realizado um controle de constitucionalidade acerca da Lei de Anistia. Na petição o pedido principal foi pela aplicação da técnica de interpretação conforme a Constituição visando a que a anistia concedida aos crimes políticos e conexos não fosse estendida aos crimes comuns praticados por agentes do Estado contra opositores políticos do regime militar entre 1964 a 1985 (BRASIL, 2008, p. 29). Ao apreciar a matéria, decidiu o STF pela conformidade da lei de Anistia com a $\mathrm{CF} / 88$, resultando na impossibilidade de apuração e criminalização de vários crimes contra a humanidade, praticados por diversos agentes políticos durante o período da ditadura, de 02 de setembro de 1961 e 15 de agosto de 1979.

Importante advertir que quando da proposição da mencionada ADPF o que a OAB almejava era o julgamento dos atos criminosos praticados durante a ditadura no Brasil que são tipificados como crimes comuns, em um procedimento de controle concentrado de constitucionalidade $^{19}$. Em uma ADPF, pelo viés do procedimento em si, o protagonismo sobre a versão oficial dos fatos sai da arena política clássica e insere-se no âmago do Poder Judiciário, representado pelo Supremo Tribunal Federal, razão de inúmeras críticas (ARGUELHES; RIBEIRO, 2016). Essa realocação do debate - que na essência é político - desloca e demonstra a fragilidade atual da ideia de separação de poderes, com proeminência para o Judiciário, matéria bastante debatida na Ciência Política, e que no direito foi cunhada de supremocracia (VIEIRA, 2018, p. 443), correspondendo à tensão entre democracia e representação política, implicando em dois momentos que se seguem: o primeiro, atinente à autoridade adquirida pelo Supremo Tribunal Federal, e, posteriormente, à expansão deste poder em relação aos demais (VIEIRA, 2008, p. 442).

Tudo isto reflete, mais uma vez, uma fragilidade democrática nos tempos atuais transparecendo que o povo não consegue dirimir seus conflitos por meio da representação política, exigindo, requerendo ou permitindo que o Judiciário se arvore a árbitro de tensões de jaez político e moral. Essa mudança de papéis - ou de importância no cenário institucional dos Poderes no Brasil - é percebida pelo fato de que nos trinta anos da Constituição de 1988, o Judiciário saiu de uma situação de marginalidade e adquiriu status proeminente, às vezes

\footnotetext{
19 A importância de a discussão sobre a ditadura ser realizada por meio do controle concentrado de constitucionalidade decorre do efeito erga omnes e eficácia vinculante aos Poderes Executivo e Judiciário atrelados ao modelo de ação escolhida.
} 
ativista, e em outras situações assumiu a posição de ser o prolator da "última palavra" "20, albergando demandas daqueles que ao longo da história se viram silenciados ou não representados adequadamente (ARGUELHES; RIBEIRO, 2016, p.408).

Sem sombra de dúvida, as vítimas da ditadura não tiveram (ou têm) representação política adequada, pois, se assim o fosse, a norma jurídica traria em seu cerne todas as demandas que a justiça de transição avoca para si, como a punição para os agentes estatais que cometeram crimes comuns durante a ditadura, ao invés de anistiar de maneira abrangente a prática dos crimes cometidos. A falta de representação política adequada (VIEIRA, 2008, p. 443) é espécie de bloqueio institucional ${ }^{21}$ significativo que rompe com os conceitos de igualdade e justiça, escancara o fracasso do Estado quanto a sua tarefa de fazer a coisa certa ${ }^{22}$ e desloca, em grande parte das vezes, os entreveros políticos ao Judiciário.

O deslocamento para o Supremo da decisão sobre a questão, e também da última palavra (VIEIRA, 2008, p. 447) que conclui o debate, rompe com a premissa de deferência que deveria ser a lógica relacional entre Legislativo e Judiciário, ou seja, o Supremo em diversos momentos se considera competente não apenas para realizar controle de constitucionalidade como também para "inovar na ordem jurídica" (VIEIRA, 2008, p. 452), além de "comparar a qualidade constitucional das decisões parlamentares com as soluções que a própria Corte venha a imaginar, substituindo as decisões do parlamento caso entenda que as suas são melhores" (VIEIRA. 2008, p. 452). Todas as críticas apontadas devem ser lembradas e servem de pano de fundo para uma reflexão quanto a decisão da $\mathrm{ADPF}$ 153, mesmo que, em um primeiro momento, o Supremo tenha consignado como argumento que a lei em si da anistia não pode ser modificada pelo Supremo, in litteris:

[...] nem mesmo o Supremo Tribunal Federal está autorizado a rescrever leis de anistia. 8. Revisão de lei de anistia, se mudanças do tempo e da sociedade a impuserem, haverá --- ou não --- de ser feita pelo Poder Legislativo, não pelo Poder Judiciário. Daí não ter sentido questionar-se se a anistia, tal como definida pela lei, foi ou não recebida pela Constituição de 1988; a nova Constituição a

\footnotetext{
${ }^{20}$ Ver trabalho de Rodrigo Brandão sobre o tema: PESSANHA, Rodrigo Brandão Viveiros. Supremacia Judicial: trajetória, pressupostos, críticas e a alternativa dos diálogos constitucionais. 2011. $456 \mathrm{f}$. Tese (Doutorado). Universidade do Estado do Rio de Janeiro, Faculdade de Direito, Rio de Janeiro, 2011.

${ }^{21} \mathrm{Um}$ desafio bastante intrincado nos tempos atuais tem sido os bloqueios institucionais. Em diversos momentos demandas atinentes a direitos fundamentais são bloqueadas por falta de representação política adequada. Em tais momentos se tem buscado no Judiciário a resposta jurídica negada na esfera política. No Brasil, Carlos Alexandre de Azevedo Campos traz em sua tese de doutorado debate interessante relacionado ao estado de coisas inconstitucional quanto a situação carcerária. Conferir: CAMPOS, Carlos Alexandre de Azevedo. Da inconstitucionalidade por omissão ao "Estado de coisas inconstitucional". 2015. 248 f. Tese (Doutorado) - Curso de Direito, Centro de Ciências Sociais, Universidade do Estado do Rio de Janeiro, Rio de Janeiro, 2015.

${ }^{22}$ Como é debatido no texto de Sandel. Conferir: SANDEL, Michael J., Justiça - O que é fazer a coisa certa, Tradução de Heloísa Matias e Maria Alice Máximo, Rio de Janeiro, Ed. Civilização Brasileira, 2011, 350 p.
} 
[re]instaurou em seu ato originário. A Emenda Constitucional n. 26/85 inaugura uma nova ordem constitucional, consubstanciando a ruptura da ordem constitucional que decaiu plenamente no advento da Constituição de 5 de outubro de 1988; consubstancia, nesse sentido, a revolução branca que a esta confere legitimidade (BRASIL, 2010).

A teoria acerca do direito constitucional intertemporal se encarrega de dissolver o argumento consignado acima (SOUZA NETO; SARMENTO, 2016) já que uma das modalidades da ação de descumprimento de preceito fundamental é a comparação entre textos anteriores e a Constituição, fazendo um juízo de adequação ou compatibilidade entre os mesmos, o que resulta na recepção ou não de textos anteriores à Constituição. É exatamente esta a situação aqui albergada. Ou seja, a decisão do Supremo ao manter o texto da lei de anistia não fez mera deferência ou teve uma preocupação no sentido de o Supremo não se imiscuir em uma função de legislador constituinte permanente (ARGUELHES; RIBEIRO, 2016) como costuma fazer quando quer, mas, sim, em manter uma convicção política por ele defendida acerca da ditadura, história e memória ${ }^{23}$.

Além disso, ainda que haja toda força vinculante atribuída à decisão, não se pode olvidar que a manutenção do texto da Lei de 1979, que prima pela anistia quanto aos crimes conexos com os políticos praticados durante a ditadura, rompe com o ideário do Estado que se constituiu a partir do texto da Constituição de 1988, além dos compromissos internacionais assumidos em prol da consolidação dos Direitos Humanos no Brasil. Nesse caso, então, não seria necessário apenas deferência, mas uma navalha forte o suficiente para separar o joio do trigo e manter a essência da Constituição, assim como sua força normativa (HESSE, 1991).

A posição do Supremo ao reconhecer a constitucionalidade da lei de anistia, repise-se, é discrepante dos anseios da Corte Interamericana sobre o tema, e exatamente acreditando nesta postura, familiares de desaparecidos políticos durante a Guerrilha do Araguaia ${ }^{24}$, recorreram ao Sistema Interamericano de Direitos Humanos, inicialmente denunciando a omissão do mesmo em fornecer justa reparação na Comissão Interamericana de Direitos Humanos e, posteriormente, junto à Corte Interamericana de Direitos Humanos, no caso que ficou conhecido como Gomes Lund e outros (“Guerrilha do Araguaia”) x Brasil.

\footnotetext{
${ }^{23}$ Frise-se que o Supremo quando quer ultrapassar os limites de deferência o faz sem maiores pudores (VIEIRA, 2008), como o que ocorreu com a interpretação dada ao instituto do mandado de injunção ao longo dos anos (ARGUELHES; RIBEIRO, 2016).

${ }^{24}$ De maneira sucinta, a Guerrilha do Araguaia foi um movimento guerrilheiro existente entre o fim da década de 1960 e a primeira metade da década de 1970 que tinha por objetivo estimular uma revolução socialista e derrubar o governo militar local. Ocorre que, em um momento de rígida ditadura, o Exército brasileiro promoveu entre 1972 e 1975 várias operações com o objetivo de erradicar a guerrilha, sendo responsável por inúmeros crimes, como: detenção arbitrária, tortura e desaparecimento forçado.
} 
Com efeito, a Corte Interamericana de Direitos Humanos, invocando precedentes jurisprudenciais anteriores, de sua própria lavra, decidiu em 24 de novembro de 2010 (aproximadamente seis meses depois da decisão do STF na ADPF 153) pela responsabilização do Brasil e pela incompatibilidade da sua lei da anistia com a Convenção Americana ${ }^{25}$. Para a Corte, o Brasil, por meio do Supremo Tribunal Federal, ao confirmar a constitucionalidade de sua lei nacional de anistia afetou o dever internacional do Estado de investigar e punir as graves violações de direitos humanos. Posteriormente a este entendimento, o Brasil não mais voltou a analisar a questão, que se encontra em sede de embargos de declaração. Em breve o caso será novamente apreciado e, para que a justiça de transição seja realmente efetivada, o entendimento deverá ser alterado para considerar a Lei de Anistia inconstitucional.

Em verdade, a existência de Lei de Anistia impede que crimes sejam apurados e que os agentes perpetradores de violências sejam responsabilizados, além de impedir a efetivação de outros pilares da justiça transicional. Para Eduardo Loureiro Lemos (2014, p. 81):

[...] o interessante é notar que a anistia representa o debate entre a memória e o esquecimento. Pode significar, a depender da concepção adotada, a luta contra o apagar das lembranças (direito à memória) ou a pacificação por meio do esquecimento.

Por sua vez, de acordo com Flávia Piovesan (2014, p. 669):

[...] a justiça de transição deve implicar em um desenvolvimento institucional sustentável na esfera democrática, na busca de restaurar o rule of law, fortalecendo mecanismos de prevenção e reparação de violações de direitos humanos e aprimorando mecanismos de responsabilização individual aos perpetradores de abusos de direitos humanos.

Portanto, repise-se, o entendimento de que a Lei de Anistia é constitucional deverá ser rechaçado pelo STF como forma de viabilizar a justiça de transição, e também como mecanismo de assegurar direito à verdade e memória, à justiça, e as reformas institucionais, demonstrando que comportamentos que geraram violência e atos atentatórios aos direitos humanos não são

\footnotetext{
25 A partir do momento em que o Brasil internaliza Tratados de Direitos Humanos, especialmente a Convenção Americana de Direitos Humanos, é necessária uma interação entre a Corte Interamericana de Direitos Humanos e as Cortes Nacionais, como o Supremo Tribunal Federal. Nesse sentido, que o Poder Judiciário, além do trivial controle de constitucionalidade, também deverá exercer um controle de convencionalidade entre as normas jurídicas internas e as normas internacionais de direitos humanos, dentre elas, e especialmente, a Convenção Americana sobre Direitos Humanos (Pacto de São José da Costa Rica), por se tratar do mais importante documento regional americano de defesa dos direitos humanos. Desta forma, enquanto o controle de constitucionalidade utiliza como paradigma o texto da Constituição, o controle de convencionalidade utiliza como paradigma o texto das convenções internacionais sobre direitos humanos que o Estado se obrigou a cumprir.
} 
aceitos e não mais fazem parte de um Estado Democrático de Direito. Ocorre que, como apontado por Arguelhes e Ribeiro (2016, p. 425-428), o Supremo tem o controle de sua pauta política e, ainda, inova em manobras para justificar decisões políticas que fogem, em vários momentos, da análise jurídica. Não se trata, neste momento, de pensar somente no texto legal estampado, mas em uma perspectiva de justiça e de alinhamento com toda a construção de direitos humanos levada a efeito e relativa a prática de atos arbitrários e violentos por parte de regimes ditatoriais.

Rever a decisão da ADPF 153 por meio dos embargos de declaração não é apenas possível, mas necessário, salvo se o desejo da Corte for a manutenção de uma legalidade positivista abraçada a um simbolismo constitucional (NEVES, 2007) que enfraquece o compromisso estatal com os Direitos Humanos e fundamentais. A Lei de Anistia representa um entrave para o conhecimento da verdade e para a justiça, caracteriza um obstáculo para que reformas institucionais sejam realmente efetivadas.

Além disso, se o argumento for pela deferência ao texto da lei de anistia, entendendo-se por deferência a "postura respeitosa que muitos tribunais demonstram em relação ao legislador, democraticamente eleito" (VIEIRA, 2008, p. 452), deve-se retomar o precedente da ADPF 132, conhecido e debatido na doutrina nacional, onde o STF modificou o entendimento de norma constitucional para abarcar a possibilidade de união de pessoas do mesmo sexo considerando a "existência de uma lei inadequada" (ARGUELHES; RIBEIRO, 2016, p. 433). No caso da ADPF 153 não se almeja a alteração do entendimento sobre norma constitucional, mas infraconstitucional que verdadeiramente não está de acordo com a proposta de redemocratização advinda da Constituição de 1988. Logo, rever a decisão da ADPF 153 não é apenas possível, mas necessário.

Não se pode afirmar que o Brasil toma todas as medidas para ser um Estado Democrático de Direito se não consegue olhar para seu passado e admitir seus erros, se não consegue declarar a inconstitucionalidade de uma Lei que em um primeiro momento até serviu de impulso para que a democracia fosse instaurada, mas, posteriormente, visualizou-se que nada mais significou do que uma impunidade.

No momento em que se vive uma determinada situação não é possível que se tenha uma real dimensão do significado dos acontecimentos, e isso aconteceu com a Lei de Anistia. A Lei de Anistia, quando foi firmada, pareceu ser um acordo bilateral de vontades para uns, entretanto, como se observa em Abrão \& Torelly (2014), por não se verificar a existência de uma relação de igualdade e equidade entre os supostos sujeitos do acordo, mostrou-se como uma imposição 
por parte dos militares. Assim, considerando o contexto histórico em que este suposto "acordo" foi firmado, que não carrega consigo características de efeitos éticos e normativos capazes de caracterizar acordos firmados em tempos de liberdade e democracia (ABRÃO \& TORELLY, 2014, p. 68), tem-se que a lei de anistia deve ser considerada como uma lei de autoanistia e não um acordo bilateral.

Em suma, dentre as várias medidas que deverão ser observadas destaca-se a declaração de inconstitucionalidade da Lei de Anistia Brasileira por violação simultânea a Convenção Americana de Direitos Humanos e à atual ordem constitucional, que deve ser interpretada em conjunto com a Convenção Americana de Direitos Humanos. Considerando que a aceitação de leis de autoanistia em nosso ordenamento nada mais significa do que a incompletude de uma justiça transicional, o reconhecimento pelo STF da inconstitucionalidade da lei de anistia é medida que se impõe.

\section{CONCLUSÃO}

Diante do exposto, é possível concluir que a justiça de transição no Brasil não foi realmente levada a efeito em todas as exigências que tem por si mesma, de modo que é possível atribuir a isso a continuidade de condutas autoritárias e violentas, especialmente no pilar transicional das reformas institucionais. Assim, inúmeras medidas devem ser efetivadas para que realmente ocorra essa descontinuidade para com um regime em que as condutas eram tidas como arbitrárias para um regime democrático, que deve ter condutas liberais e humanas.

Nesse sentido, a mudança de entendimento do STF a respeito da Lei de Anistia, de modo a declará-la inconstitucional, é medida que se impõe, por ser um importante mecanismo para consolidar a democracia e promover um diálogo jurisdicional entre a Corte Interamericana de Direitos Humanos e o STF. Agindo assim, medidas reparatórias atinentes à justiça de transição estarão sendo efetivadas; a promoção do reconhecimento, a verdade, a memória, a justiça e as reformas institucionais estarão sendo viabilizadas.

A tortura, uma das violências mais graves cometidas durante a época da ditadura, continua sendo praticada nos dias atuais, e continuará a ser praticada no futuro, se mudanças drásticas não forem tomadas. De nada adianta a tomada de medidas paliativas e o respeito a alguns pilares da justiça de transição de forma aleatória, como o pilar da reparação, se a estrutura e o pano de fundo não forem mudados. É preciso mudar as bases, enfrentar o cerne do problema, pois temos um problema estrutural. 
Se antes, na época do regime civil-militar, a tortura era praticada destacadamente contra aqueles que se opunham ao regime, hoje sua prática ocorre no mais das vezes contra classes vulneráveis. Os agentes de segurança pública, carregando resquícios da época ditatorial, e acreditando na impunidade dos seus atos, muitas das vezes são responsáveis por tais episódios.

Ocorre que não se faz uma democracia encobertando determinadas práticas abusivas, autoritárias e arbitrárias. Uma democracia só é plenamente possível se tais condutas forem rechaçadas. E para que tais condutas sejam afastadas é preciso que haja um reconhecimento de que tais práticas existiram, de que o Estado errou, de que agentes públicos cometeram diversos crimes. Havendo este reconhecimento um largo passo é dado em direção à democratização.

Reconhecer os erros do passado, punir os crimes ocorridos, reformar as instituições responsáveis pelo cometimento de tais crimes são formas de promover a memória, a verdade, e a justiça, construindo um presente e viabilizando um futuro democrático.

\section{REFERÊNCIAS}

ABRÃO, Paulo; GENRO, Tarso. Os direitos da transição e a democracia no Brasil: estudos sobre Justiça de Transição e teoria da democracia. Belo Horizonte: Fórum, 2012. 208 p. (Coleção Fórum Justiça e Democracia, v.1).

ABRÃO, Paulo; TORELLY, Marcelo. Mutações do conceito de anistia na justiça de transição brasileira: a terceira fase da luta pela anistia. In: Giuseppe Tosi...[et al.], (Organizadores). Justiça de transição: direito à justiça, à memória e à verdade. João Pessoa: Editora da UFPB, 2014. 348p. (Coleção Direitos Humanos). p. 63-86.

AMBOS, Kai et al. Anistia, justiça e impunidade: reflexões sobre a justiça de transição no Brasil. Belo Horizonte: Fórum, 2010.

ANISTIA INTERNACIONAL. Chacina da Candelária 25 anos: lembramos dessa história para que ela não se repita. 2013. Disponível em: <https://anistia.org.br/noticias/nota-publica20-anos-da-chacina-da-candelaria-nao-vamos-esquecer/>. Acesso em: 22 de outubro de 2018.

ANISTIA INTERNACIONAL. Chacina do Carandiru, o mal que persiste entre nós. 2016. Disponível em: <https://anistia.org.br/chacina-carandiru-o-mal-que-persiste-entre-nos/> . Acesso em: 22 de outubro de 2018.

ANISTIA INTERNACIONAL. Nota pública: Anistia Internacional pede investigação rigorosa sobre chacina na região da Grande São Paulo. 2015. Disponível em: $<$ https://anistia.org.br/noticias/nota-publica-anistia-internacional-pede-investigacao-rigorosasobre-chacina-na-regiao-da-grande-sao-paulo/>. Acesso em: 22 de outubro de 2018. 
ARGUELHES, Diego Werneck; RIBEIRO, Leandro Molhano. Criatura e/ou Criador: transformações do Supremo Tribunal Federal sob a Constituição de 1988. Revista Direito GV, São Paulo, v.12, n. 2, p. 405-440, mai-ago 2016. Disponível em: <http://www.scielo.br/pdf/rdgv/v12n2/1808-2432-rdgv-12-2-0405.pdf >. Acesso em: $21 \mathrm{de}$ janeiro de 2019.

AVRITZER, Leonardo. Cultura política, atores sociais e democratização. Uma crítica às teorias de transição para a democracia. Revista Brasileira de Ciências Sociais, São Paulo, n. 28, p. 109-122, jun. $1995 . \quad$ Disponível em: <http://www.anpocs.org.br/portal/publicacoes/rbcs_00_28/rbcs28_09.htm>. Acesso em: 14 de novembro de 2018.

BAGGIO, Roberta Camineiro. Justiça de Transição como reconhecimento: limites e possibilidades do processo brasileiro. Cadernos IHU ideias, São Leopoldo, ano 12, vol. 12., n.208, 2014.

Silva, Alexandre Garrido (Org.). Democracia e justiça de transição: memória e resistência política no Brasil. Uberlândia: EDUFU, 2015. 474 p.

BAGGIO, Roberta Camineiro. MIRANDA, Lara Caroline; A incompletude da transição política brasileira e seus reflexos na cultura jurídica contemporânea: ainda existem perseguidos políticos no Brasil? In: Silva, Alexandre Garrido (Org.). Democracia e justiça de transição: memória e resistência política no Brasil. Uberlândia: EDUFU, 2015. 474 p.

BARROSO, Luís Roberto. O Direito Constitucional e a efetividade de suas normas - limites e possibilidades da constituição brasileira. Rio de Janeiro: Renovar, 2a edição, 1993.

BRASIL. Comissão Nacional da Verdade. Parte 1. Relatório. Volume 1. Dezembro de 2014. Disponível

<http://cnv.memoriasreveladas.gov.br/images/pdf/relatorio/volume_1_pagina_17_a_82.pdf.>

Acesso em: 16 de janeiro de 2019.

BRASIL. Supremo Tribunal Federal. Arguição de descumprimento de preceito fundamental 153. Petição Inicial. Brasília, 21 de outubro de 2008. Disponível em: $<$ http://www.sbdp.org.br/arquivos/material/586_ADPF\%20153\%20-

\%20peticao\%20inicial.pdf.> Acesso em: 22 de janeiro de 2019.

BRASIL, Supremo Tribunal Federal. Arguição de Descumprimento de Preceito Fundamental n.153\DF. Relator: Min. Eros Grau. Julgamento: 29/04/2010. Órgão Julgador: Tribunal Pleno. Publicação: DJe-145 DIVULG 05-08-2010 PUBLIC 06-08-2010. EMENT VOL-02409-01. PP-00001. Disponível em: $<$ http://portal.stf.jus.br/processos/detalhe.asp?incidente=2644116>. Acesso em: 16 de janeiro de 2019.

CAMPOS, Carlos Alexandre de Azevedo. Da inconstitucionalidade por omissão ao "Estado de coisas inconstitucional". 2015. 248 f. Tese (Doutorado) - Curso de Direito, Centro de Ciências Sociais, Universidade do Estado do Rio de Janeiro, Rio de Janeiro, 2015.

COMISSÃO INTERAMERICANA DE DIREITOS HUMANOS. Convenção interamericana para prevenir e punir a tortura: assinada em Cartagena das Índias, Colômbia, em 9 de dezembro

de 1985.

Disponível

em: 
<https://www.oas.org/pt/cidh/mandato/basicos/tortura.pdf $>$. Acesso em: 26 de outubro de 2018.

DUARTE, Antônio Pereira. Apresentação. In. O Ministério Público e o controle externo da Atividade Policial: Dados 2016 / Conselho Nacional do Ministério Público. Brasília: CNMP, 2017. $220 \mathrm{p}$.

ELSTER, Jon. Rendición de cuentas: la justicia transicional en perspectiva histórica. Buenos Aires: Katz, 2006.

FACHIN, Zulmar. O Direito Humano Fundamental de não ser torturado. In. CLÈVE, Clèmerson Merlin; SARLET, Ingo Wolfgang; PAGLIARINI, Alexandre Coutinho (Coord.). Direitos Humanos e Democracia. Rio de Janeiro: Forense, 2007.

FELTRAN, Gabriel de Santis. Conflito Urbano e Gramáticas de mediação. Revistas Marquem Esquerda. Cidades em conflito; Conflitos nas cidades. São Paulo: Editora Boitempo, 2015, p.13-16.

HESSE, Konrad. A força normativa da Constituição. Trad. Gilmar Ferreira Mendes. Porto Alegre: Sérgio Fabris Editor. 1991.

HONNETH, Axel. Luta por reconhecimento: a gramática moral dos conflitos sociais. São Paulo: Ed.34, 2003.

JESUS, Maria Gorete Marques de. (Coord.), e CALDERONI, Vivian (Coord.). Julgando a tortura: análise da jurisprudência nos tribunais de justiça do Brasil (2005-2010). $1^{\mathrm{a}}$ ed. São Paulo, Jan/2015. Disponível em: <http://br62.teste.website/ redejust/wpcontent/uploads/2016/09/Julgando-a-tortura-An\%C3\%A1lise-de-jurisprud\%C3\%AAncia-nosTribunais-de-Justi\%C3\%A7a-do-Brasil-2005-2010.pdf>. Acesso em: 17 de janeiro de 2019.

LEAL, Rogério Gesta. Verdade, memória e justiça no Brasil: responsabilidades compartidas - morte, tortura, sequestro e desaparecimento de pessoas no regime militar brasileiro - de quem é a responsabilidade? Porto Alegre: Livraria do Advogado, 2012.

LEME, Heládio José de Campos. Ditadura, repressão e memória. In: Silva, Alexandre Garrido (Org.). Democracia e justiça de transição: memória e resistência política no Brasil. Uberlândia: EDUFU, 2015. 474 p.

LEMOS, Eduardo Loureiro. Justiça de Transição: análise da efetivação da justiça histórica e criminal no Brasil. Belo Horizonte: Editora D’Plácido, 2014.

LUNARDI, Fabrício Castagna. A justiça de transição no Brasil a transição política, a reforma das instituições e o desenvolvimento da democracia. Revista dos Tribunais. Vol. 924/2012. p. 153- 187. Out/2012.

MEYER, Emilio Peluso Neder; CUNHA, Raíssa Lott Caldeira. O papel das Comissões da Verdade e dos processos criminais na desconstrução da história oficial e na construção de uma memória não obrigada. In: ALVES, Cândice Lisboa (Org.). Vulnerabilidades e 
invisibilidades: desafios contemporâneos para a concretização dos direitos humanos. Belo Horizonte: Arraes Editores, 2015. 336p.

NEVES, Marcelo. A constitucionalização simbólica. São Paulo: WMF Martins Fontes, 2007.

PESSANHA, Rodrigo Brandão Viveiros. Supremacia Judicial: trajetória, pressupostos, críticas e a alternativa dos diálogos constitucionais. 2011. 456 f. Tese (Doutorado). Universidade do Estado do Rio de Janeiro, Faculdade de Direito, Rio de Janeiro, 2011.

PIOVESAN, Flávia. Justiça de transição, reformas institucionais e consolidação do Estado Democrático de Direito: o caso brasileiro. In: MEYER, Emilio Peluso Neder; OLIVEIRA, Marcelo Andrade Cattoni de (Org.). Justiça de Transição nos 25 anos da Constituição de 1988. Belo Horizonte: Initia Via, 2014, 798 p.

RODRIGUES, Ricardo C. de Carvalho. Continuidade Autoritária: as bases para o grande encarceramento. Revista Brasileira de Ciências Criminais. vol. 129. 2017. p. 349-373.

SAAVEDRA, Giovani. Segurança vs. Dignidade - o problema da tortura revisitado pela criminologia do reconhecimento. Revista de Filosofia da PUCRS. Porto Alegre: Veritas, v. 53, n. 2, 2008. Disponível em: <https://core.ac.uk/download/pdf/25530867.pdf〉. Acesso em: 22 de janeiro de 2019.

SANDEL, Michael J., Justiça - O que é fazer a coisa certa, Tradução de Heloísa Matias e Maria Alice Máximo, Rio de Janeiro, Ed. Civilização Brasileira, 2011, 350 p.

SILVA FILHO, José Carlos Moreira da; ABRÃO, Paulo; TORELLY, Marcelo D. (Coord.). Justiça de Transição nas Américas: olhares interdisciplinares, fundamentos e padrões de efetivação. Belo Horizonte: Fórum, 2013.

SILVA FILHO, José Carlos Moreira da. O terrorismo de estado e a ditadura civil-militar no brasil: direito de resistência não é terrorismo. In: Revista Anistia Política e Justiça de Transição / Ministério da Justiça. Brasília: Ministério da Justiça, n. 5, 2012, p. 50-75.

SISTEMA INTERAMERICANO DE DIREITOS HUMANOS. Convenção Interamericana para Prevenir e Punir a Tortura: assinada em Cartagena das Índias, Colômbia, em 9 de dezembro de 1985. Disponível em: <http://www.oas.org/juridico/portuguese/treaties/a51.htm>. Acesso em 22 de junho de 2018.

SOUZA NETO, Cláudio Pereira de; SARMENTO, Daniel. Direito constitucional: teoria, história e métodos de trabalho. Imprenta: Belo Horizonte, Fórum, 2016.

SWENSSON JUNIOR, Lauro Joppert. Punição para os crimes da ditadura militar: contornos do conflito. In: DIMOULIS, Dimitri; MARTINS, Antônio; SWENSSON JUNIOR, NEUMANN, Ulfrid; Lauro Joppert (Org.). Justiça de Transição no Brasil: direito, responsabilidade e verdade. São Paulo: Saraiva, 2010.

TEITEL, Ruti. Trasitional Justice Genealogy. Havard Human Rights Journal, v. 16, 2003 p. 69-94. Disponível em: <http://www.nyls.edu/faculty/wp- 
content/uploads/sites/148/2013/09/Harvard-Human-Rights-Journal.pdf $>$. Acesso em: 17 de janeiro de 2019.

TORELLY, Marcelo. Das Comissões de Reparação à Comissão da Verdade: contribuições da Comissão sobre os Mortos e Desaparecidos Políticos (1995) e da Comissão da Anistia (2001) para a Comissão Nacional da Verdade. In: TOSI, Giuseppe (et al.). Justiça de Transição: direito à justiça, à memória e à verdade. João Pessoa: Editora da UFPB, 2014.

TORELlY, Marcelo D. Justiça de Transição e Estado Constitucional de Direito: perspectiva teórico-comparativa e análise do caso brasileiro. Belo Horizonte: Fórum, 2012. (Coleção Fórum Justiça e Democracia, v.2).

VIEIRA, Oscar Vilhena. Supremocracia. Revista Direito GV, São Paulo v.4, n. 2, p. 441-464, jul-dez 2008. Disponível em: 〈http://www.scielo.br/pdf/rdgv/v4n2/a05v4n2.pdf> . Acesso em: 21 de janeiro de 2019.

ZAVERUCHA Jorge. Relações Civil-Militares: o legado autoritário da constituição brasileira de 1988. In: TELES, Edson; SAFATLE, Vladimir (Orgs.). O que resta da ditadura. São Paulo: Boitempo, 2010

ZYL, Paul Van. Promovendo a Justiça Transicional em Sociedades Pós-Conflito. In: Justiça de Transição: manual para a América Latina/coordenação de Félix Reategui. - Brasília: Comissão de Anistia, Ministério da Justiça; Nova York: Centro Internacional para a Justiça de Transição, 2011. 576 p.

Trabalho recebido em 15 de março de 2019

Aceito em 14 de junho de 2020 